\title{
The Roma and European Union citizenship:

\author{
in search of a humane answer from the $E U$
}

\author{
Nuno Ferreira and Dora Kostakopoulou*
}

\section{Introduction}

'The Roma' has become the staple terminology in studies and policy-making related to a broad group of individuals and communities who, although having only limited cultural affinity, share similar experiences of socio-economic deprivation due to a range of factors. Because of this shared experience of deprivation, all these individuals and groups have - out of policy and terminology convenience, it must be admitted - been included within a broad, somewhat inaccurate notion of Roma. ${ }^{1}$ This notion usually includes peoples who define themselves as Roma, Gypsies, Travellers, Manouches, Ashkali and Sinti, among others. The significance of this group is not only socio-economic but also, undoubtedly, numerical: it is estimated that there are nowadays around six million Roma in the EU and twelve million overall in Europe. ${ }^{2}$ Moreover, there are four million Roma in Turkey and one million in the

\footnotetext{
* The authors wish to thank Amandine Garde, Nikos Vogiatzis and Samantha Currie for their insightful comments on earlier versions of this work, and Alison Morley for the thorough copy-editing.

${ }^{1}$ It is acknowledged, however, that using such an umbrella term raises important cultural and social problems, namely the essentialising of who is a member of the 'Roma', undue account of the existing diversities within this group, and the impact of this terminology on power relations between local elites and marginal groups within the Roma: Annabel Tremlett, 'Making a Difference Without Creating a Difference: De-essentialising Debates on "the Roma” Without Losing Sight of Ethnicity’, UACES annual conference, Leeds, 2013. Also, several nomadic groups, usually referred to as 'Travellers', are not of Roma-Indian origin, having only their nomadism in common with many other Roma peoples: William K. Barth, 'Minority rights, multiculturalism and the Roma of Europe' (2007) 76 Nordic Journal of International Law 363-406, 374.

${ }^{2}$ European Commission, European Commission calls on Member States to set national strategies for Roma integration, IP/11/400, Strasbourg, 5 April 2011.
} 
Western Balkans, ${ }^{3}$ which means that a possible future EU enlargement to these regions would increase considerably the Roma population in the EU, and would bring to the fore a range of linked socio-economic challenges. The EU's concern in this regard is demonstrated by the $€ 100$ million that it has offered in pre-accession assistance to support Roma inclusion. ${ }^{4}$

Although the historical detail lacks certainty, it is believed that the Roma's origins lie in India and that their arrival in Europe dates back to the tenth century. ${ }^{5}$ As the Roma never acquired a permanent territorial basis, the European Parliament has defined them as a 'panEuropean ethno-cultural community without a nation' ${ }^{6}$ The Roma can thus be seen as a 'nonterritorial nation', posing an interesting challenge to the still prevailing Westphalian model of international relations and sovereignty. ${ }^{7}$ Roma communities and individuals have, however, increasingly organised themselves to present a collective voice at a domestic and transnational level, which may empower them and assist them in achieving change. The European Roma Rights Centre (ERRC), for example, has become a key actor in fighting racial discrimination against Roma, including through strategic litigation that has involved the European Court of Human Rights. ${ }^{8}$

Ever since the Roma arrived in Europe, their lives have been marked by consistent persecution and discrimination, including extreme violence and even annihilation programmes. This is attributed, to a great extent, to their nomadic life style. ${ }^{9}$ The range of problems still afflicting the lives of many Roma nowadays is extremely wide, well researched and extensively

\footnotetext{
${ }^{3}$ European Commission, Communication from the Commission to the European Parliament, the Council, the European Economic and Social Committee and the Committee of the Regions: Report on the implementation of the EU Framework for National Roma Integration Strategies, Brussels, 2 April 2014, COM(2014) 209 final, section 4.

${ }^{4}$ Ibid.

${ }^{5}$ Barth, 'Minority rights, multiculturalism and the Roma of Europe', $370 \mathrm{ff}$.

${ }^{6}$ European Parliament resolution of 10 July 2008 on the census of the Roma on the basis of ethnicity in Italy, P6_TA(2008)0361, para. F.

${ }^{7}$ Marton Rovid, 'The Cosmopolitan Gypsy: On the Transcendence of National Citizenship in the Light of the Case of Roma, an Allegedly Non-territorial Nation', UACES annual conference, Leeds, 2013.

$8<$ http://www.errc.org/index.php> accessed 30 March 2015.

${ }^{9}$ Barth, 'Minority rights, multiculturalism and the Roma of Europe', $377 \mathrm{ff}$ and $397 \mathrm{ff}$.
} 
documented. ${ }^{10}$ The most commonly mentioned difficulties include lack of access to or segregated education, ${ }^{11}$ reduced access to or poor quality healthcare, ${ }^{12}$ below standard housing and forced evictions, ${ }^{13}$ anti-Roma violence and harassment (including by police officers), ${ }^{14}$ and even racist statements from politicians. ${ }^{15}$

In the light of the challenges affecting the Roma, the Council of Europe (CoE) has been at the forefront of the fight against the violation of human rights suffered by this minority. The CoE has not only produced the Framework Convention for the Protection of National Minorities, ${ }^{16}$ but also a range of Roma-specific policy measures, including the 2008 recommendation on policies for Roma and/or Travellers in Europe. ${ }^{17}$ These documents have set the tone of much subsequent policy (including at EU level) and contributed to a range of positive changes.

The EU has also increasingly taken on the role of policy-maker with regard to the Roma minority. The existence of a web page on the EU's website dedicated exclusively to the Roma is perhaps the most obvious indicator that the EU also assumes responsibility in this regard especially considering that the web page in question starts off by stating that ' $[\mathrm{t}] \mathrm{he}$ European institutions and every EU country have a joint responsibility to improve the lives of the EU's Roma citizens' ${ }^{18}$ Although the EU's interest in the lives of the Roma may only have become

\footnotetext{
10 Ibid, 376.

${ }^{11}$ For example, in Romania: Maria Roth and Florin Moisa, 'The right to education of Roma children in Romania: European policies and Romanian practices' (2011) 19 International Journal of Children's Rights 501-522; in several other EU Member States even in 2014, European Commission, Report on the implementation of the EU Framework for National Roma Integration Strategies, section 3.1.

12 European Commission, Report on the implementation of the EU Framework for National Roma Integration Strategies, section 3.3.

${ }^{13}$ European Commission, Report on the implementation of the EU Framework for National Roma Integration Strategies, section, 3.4.

${ }^{14}$ Amnesty International, "We ask for Justice”: Europe's failure to protect Roma from racist violence, Amnesty International, 2014.

15 Ibid, pp. 6 and 26; Nick Thorpe, 'The baby that divided a nation', 9 February 2015, <http://www.bbc.co.uk/news/magazine-31168246> accessed 30 March 2015.

16 Strasbourg, 1 February 1995, entered into force on 1 February 1998.

${ }^{17}$ Recommendation CM/Rec(2008)5 of the Committee of Ministers to member states on policies for Roma and/or Travellers in Europe (adopted by the Committee of Ministers on 20 February 2008 at the 1018th meeting of the Ministers’ Deputies).

$18<$ http://ec.europa.eu/justice/discrimination/roma/index_en.htm> accessed 30 March 2015.
} 
so serious due to the enlargement process and accession of countries with significant Roma minorities, ${ }^{19}$ subsequent work and interventions denote a much broader interest and ambitious agenda. Indeed, the potential of the tools available to the EU in the fight against Roma social and economic deprivation has been recognised by the Commission and Council from early on. ${ }^{20}$ The EU has thus progressively adopted a 'mainstreaming' approach to Roma policy, ${ }^{21}$ and considers Roma needs and interests across all relevant EU policies: from free movement to social policy, from discrimination to cohesion policy, from neighbourhood to enlargement policies. The focus has, in any case, remained on social and economic integration, in particular in four priority areas: education, employment, housing and healthcare. ${ }^{22}$

In this work, we wish to concentrate on the Roma as EU citizens, particularly on their use of the Citizenship Directive, an instrument explored in detail in other contributions to this book. ${ }^{23}$ Indeed, Roma migration within the EU has been at the core of many of the contentious events and heated debates surrounding the Roma since the mid-2000s. Oddly enough, free movement is almost invisible in the EU Framework for National Roma Integration Strategies. ${ }^{24}$ It is essential to assess the EU's role in this context and, in particular, enquire into the degree of humaneness of the EU policy in this regard, building upon the framework proposed in the Introduction to this book. To do so, we start by setting out the key events that have made Roma migration such an important topic in EU law and policy (Section 2). Then we discuss some

\footnotetext{
${ }^{19}$ European Commission (Directorate-General for Employment, Social Affairs and Inclusion), The situation of Roma in an enlarged European Union, 2004.

${ }^{20}$ European Commission, Communication from the Commission to the Council, the European Parliament, the European Economic and Social Committee and the Committee of the Regions: The social and economic integration of the Roma in Europe, COM/2010/0133 final, Brussels, 7 April 2010.

${ }^{21}$ European Commission, Communication on Roma in Europe and progress Report on Roma inclusion 20082010, MEMO/10/121, Brussels, 7 April 2010; European Commission, Report on the implementation of the EU Framework for National Roma Integration Strategies, section 2.

${ }^{22}$ European Commission, Communication from the Commission to the European Parliament, the Council, the European Economic and Social Committee and the Committee of the Regions: An EU Framework for National Roma Integration Strategies up to 2020, COM/2011/0173 final, Brussels, 5 April 2011.

${ }^{23}$ Directive 2004/38/EC of the European Parliament and of the Council, of 29 April 2004, on the right of citizens of the Union and their family members to move and reside freely within the territory of the Member States amending Regulation (EEC) No 1612/68 and repealing Directives 64/221/EEC, 68/360/EEC, 72/194/EEC, 73/148/EEC, 75/34/EEC, 75/35/EEC, 90/364/EEC, 90/365/EEC and 93/96/EEC.

${ }^{24}$ European Commission, An EU Framework for National Roma Integration Strategies up to 2020.
} 
issues that affect Roma EU citizens wishing to migrate within the EU, in particular the existence of transitional periods, the overall securitisation trend in domestic migration policies, the restrictive and deficient transposition of the Citizenship Directive, and Roma cultural specificities in the context of EU free movement (Section 3). We then proceed to explore in greater detail the main issue affecting migrating Roma EU citizens, i.e. the scope for derogations from free movement provisions (Section 4). To gain a more thorough view of the role of EU citizenship in Roma lives, we also analyse how the other (mostly political) dimensions attached to EU citizenship status relate to belonging to the Roma minority (Section 5). We conclude with some thoughts on the way forward for EU policy with regard to the Roma and their status as EU citizens, particularly in what ways the EU approach can become more humane with regard to this minority in the context of free movement (Section 6).

2. The reality of Roma migration in the EU citizenship era

The Roma, being to a significant extent a nomadic people, find themselves often crossing borders, thus being migrants par excellence. This places them in a particularly fragile position, as states' border controls and policies towards foreigners affect Roma life style and cultural traditions directly and profoundly. This remains true for those Roma who are EU citizens and who have attempted to use the rights entailed by that status since the accession to the EU of their Member State of nationality.

In this context, France and Italy have attracted particularly negative attention since 2008 for their treatment of the Roma. In Italy, the authorities declared a 'Nomad Emergency' in May $2008,{ }^{25}$ and proposed to carry out the fingerprinting - free from the ordinary administrative

\footnotetext{
${ }^{25}$ Decreto del Presidente del Consiglio dei Ministri, 21 maggio 2008, Dichiarazione dello stato di emergenza in relazione agli insediamenti di comunità nomadi nel territorio delle regioni Campania, Lazio e Lombardia (Gazzetta Ufficiale n. 122 del 26-5-2008).
} 
procedural requirements - of the Roma living in camps, prompting international outrage. The Council of Europe Secretary General at the time, Terry Davis, went so far as to say that the 'proposal invites historical analogies which are so obvious that they do not even have to be spelled out' and that he believed that 'Italian democracy and its institutions are mature enough to prevent any such ideas becoming laws' ${ }^{26}$ That turned out to be excessive optimism as, despite the European Parliament's opposition, ${ }^{27}$ the Italian authorities did indeed carry out their plans to 'mass fingerprint' Roma individuals. ${ }^{28}$ The fingerprinting operation came with the blessing of the European Commission, which, after initially considering that such an initiative would violate the EU anti-discrimination and fundamental rights framework, ${ }^{29}$ eventually judged the Italian measures to be non-discriminatory after the measure was extended to the whole Italian population, lost its systematic character, and was to be carried out only as a last resort, thereby avoiding any racial bias or collective nature. ${ }^{30}$ In reality, the census appears to have been carried out with a racial motivation and without individual consideration of nationality or residence permits. ${ }^{31}$ The measures were justified by the Italian authorities on the basis that fingerprinting would allow the authorities to offer documentation to (Roma) migrants, in particular children. ${ }^{32}$ Yet it was clear to both UNICEF and the European Parliament that any intention to protect children's interests could not justify the violation of

\footnotetext{
${ }^{26}$ Council of Europe, Press Release Ref. No. 484b08, 27 June 2008.

${ }^{27}$ European Parliament resolution of 10 July 2008 on the census of the Roma on the basis of ethnicity in Italy.

${ }^{28}$ Andrew Gilmore, Italy begins mass fingerprinting of Roma minority, Jurist, 3 July 2008.

${ }^{29}$ Renata Goldirova, Italian plans to fingerprint Roma criticised as 'ethnic cataloguing', EU Observer, 27 June 2008, <http://euobserver.com/justice/26408> accessed 30 March 2015.

${ }^{30}$ Earth Times, 'Italy: EU clears Italian plans to fingerprint Roma', <https://www.crin.org/en/library/newsarchive/italy-eu-clears-italian-plans-fingerprint-roma> accessed 30 March 2015; Lucia Kubosova, 'EU gives blessing for Italy's Roma fingerprint scheme', 5 September 2008, <http://euobserver.com/justice/26691> accessed 30 March 2015.

${ }^{31}$ ERRC interview with Ms Deidda Rosa in Camp Via Tenuta Piccirilli, Rome, 10 October 2008, reported in European Roma Rights Centre (ERRC), Open Society Justice Initiative and osservAzione, Memorandum to the European Commission: Violations of EC law and the fundamental rights of Roma and Sinti by the Italian government in the implementation of the census in "nomad camps", 4 May 2009, p. 8, $<$ http://www.errc.org/cms/upload/media/03/D5/m000003D5.pdf> accessed 30 March 2015.

32 EurActiv, 'Roma MEP: Italy's fingerprinting should be seen in wider context', 31 July 2008, $<$ http://www.euractiv.com/socialeurope/roma-mep-italy-fingerprinting-seen-wider-context/article-174700> accessed 30 March 2015.
} 
those same children's fundamental rights. ${ }^{33}$ Also, although the Italian Council of State (Italy's highest administrative judicial authority) eventually declared the 'Nomad Emergency' unlawful in $2011,{ }^{34}$ discriminatory measures against the Roma have not ceased, facilitated by the approval in 2009 of a statute making undocumented stay in Italy punishable with a fine of up to $€ 10,000$. $^{35}$

The events that have taken place in France have warranted an even stronger reaction, at least initially, from the EU. The main concern regarded the widely reported 2010 forced eviction, biometric identification (the so-called 'fichier Oscar') and expulsion of any nonFrench national held to be illegally in French territory. ${ }^{36}$ French authorities attempted to justify these measures by stating that they were aimed at addressing the public order issues raised by Roma and other illicit camps, including violation of ownership, living conditions violating the principle of human dignity and public health, and instances of illicit trafficking, crime and trafficking in human beings. ${ }^{37}$ Although often referred to in the context of 'aid to return' and allegedly applicable to any non-French national, it was clear from the start that these measures would disproportionately affect the Roma minority (thus constituting indirect discrimination on grounds of ethnic background) and included EU citizens (thus most likely violating EU citizens' free movement). Also, it was clear that the biometric identification, in particular, aimed exclusively to prevent any individuals who received 'aid to return' from returning to

\footnotetext{
${ }^{33}$ European Parliament resolution of 10 July 2008 on the census of the Roma on the basis of ethnicity in Italy, para. 2.

${ }^{34}$ Sentenza del Consiglio di Stato del 16 novembre 2011, n. 6050.

${ }^{35}$ Legge 15 luglio 2009, n. 94, Disposizioni in materia di sicurezza pubblica, Gazzetta Ufficiale n. 170 del 24 luglio 2009 - Supplemento ordinario n. 128.

${ }^{36} \mathrm{Gisti} / \mathrm{Iris} / \mathrm{LDH}$, Oscar ou le déni de citoyenneté européenne des Roms, Paris, 21 September 2010; France 24, French police take DNA samples of Roma, rights group claims, 7 October 2010, $<$ http://www.france24.com/en/20101007-french-police-accused-keeping-secret-lists-roma/> accessed 30 March 2015.

${ }^{37}$ Embassy of France in Washington, D.C., European cooperation for the integration of the Roma, Brussels, 1 September 2010, <http://ambafrance-us.org/spip.php?article1833>, accessed 30 March 2015.
} 
France, which would constitute a violation of EU law with regard to Roma Romanian and Bulgarian citizens. ${ }^{38}$

Apparently, this was the culmination of a process that had started in 2006, targeting all non-French nationals, including EU citizens. ${ }^{39}$ Moreover, although the French authorities had consistently denied any intention of targeting the Roma minority, the public disclosure of three administrative instructions ('circulaires') requiring local authorities to prioritise the dismantling of Roma camps deprived the French authorities of any credibility in this matter. ${ }^{40}$ Commissioner Reding thus declared herself to be 'personally appalled' and expressed her 'deepest regrets' at the lack of reliability of the political assurances of the French authorities, besides highlighting the 'deeply disturbing' nature of this departure from the EU's common values and law. ${ }^{41}$ Commissioner Reding also demanded an 'immediate and swift explanation of the matter' and expressed her belief that an infringement action would have to be initiated against France for discriminatory application of the Citizenship Directive and for the lack of transposition of the procedural and substantive guarantees therein, finishing off with a stark warning: 'my patience is wearing thin: enough is enough' ${ }^{42}$ The warning, however, was not carried through: in a statement marred by political jargon and compromise, Commissioner Reding expressed her satisfaction with subsequent assurances from French authorities, ${ }^{43}$ including particularly the fact that the discriminatory administrative instructions had been annulled and replaced with revised versions. ${ }^{44}$ The intention to collectively discriminate against

\footnotetext{
${ }^{38} \mathrm{Gisti} / \mathrm{Iris} / \mathrm{LDH}$, Oscar ou le déni de citoyenneté européenne des Roms.

${ }^{39} \mathrm{Gisti} / \mathrm{Iris} / \mathrm{LDH}$, Oscar ou le déni de citoyenneté européenne des Roms.

${ }^{40}$ David Prochasson, 'Expulsions de Roms, un “mode d’emploi” explicite’, Le Canard Social, 13 September 2010, $<$ http://www.lecanardsocial.com/ArticleFil.aspx?i=182> accessed 30 March 2015.

${ }^{41}$ Viviane Reding, Statement on the latest developments on the Roma situation, Brussels, SPEECH/10/428, 14 September 2010.

42 Ibid.

${ }^{43}$ Viviane Reding, Statement by Viviane Reding, Vice-President of the European Commission, EU Commissioner for Justice, Fundamental Rights and Citizenship, on the recent developments concerning the respect for EU law as regards the situation of Roma in France, MEMO/10/502, Brussels, 19 October 2010.

${ }^{44}$ European Commission, European Commission assesses recent developments in France, discusses overall situation of the Roma and EU law on free movement of EU citizens, IP/10/1207, Brussels, 29 September 2010.
} 
the Roma was, however, beyond doubt by then as, first, it could not simply be a coincidence that over a thousand Roma had been expelled, ${ }^{45}$ and, secondly, the changing of the phrasing of the original administrative instructions could not mask the original motivation behind the French authorities' action. Furthermore, even if the Commission had initiated infringement proceedings against France for deficient transposition of the Citizenship Directive, this would have been seen as a 'minor rebuke to the Elysée Palace as it failed to rule on the more serious charge - whether the Sarkozy administration was in breach of fundamental EU rights by targeting the Roma for ethnic discrimination' ${ }^{46}$

These events in France and Italy were of such a serious nature that they even prompted the UN Committee on the Elimination of Racial Discrimination to intervene and in particular to criticise the possibility of collective removals. ${ }^{47}$ In contrast, the EU's lack of enforcement actions and sanctions denotes 'a lack of political will and a genuine commitment to the legal principles informing the Citizenship Directive and the Charter of Fundamental Rights' ${ }^{48}$ Ultimately, this is indicative of a clear degree of a lack of humaneness in the EU Roma law and policy.

France and Italy, amongst other EU Member States, continue to cause concern with respect to the treatment of Roma. Recent reports highlight the exclusion of children from French primary schools, ${ }^{49}$ the use of illegal ethnic databases and 'ethnic statistics' on criminality, ${ }^{50}$ and the occurrence of forced and violent evictions, often with consequent

\footnotetext{
${ }^{45}$ Helen O'Nions, 'Roma expulsions and discrimination: The elephant in Brussels' (2011) 13(4) European Journal of Migration and the Law 361-388, 380.

${ }^{46}$ Ian Traynor and Kim Willsher, 'Roma ultimatum given to France by EU: allow free movement or face court', The Guardian, 29 September 2010.

${ }^{47}$ Henry Samuel, 'UN warns France over Roma deportations', The Telegraph, 27 August 2010,

${ }^{48} \mathrm{O}$ 'Nions, 'Roma expulsions and discrimination', 365.

49 European Roma Rights Centre, No Place in School for Roma Children in France?, <http://www.errc.org/article/no-place-in-school-for-roma-children-in-france/4307> accessed 30 March 2015.

${ }^{50}$ The French so-called 'Gaspard database' on 'ethnic statistics' on criminality: Marie Martin, 'Expulsion of Roma: the French government’s broken promise’ (2013, Jan) 22(4) Statewatch . Similar claims of illegal ethnic profiling had already been made in 2010, including regarding the existence of an ethnic database called MENS (acronym for 'minorités ethniques non sedentarisés') allegedly managed by the Office Central de Lutte contre la Délinquance Itinérante (OCLDI): Henry Samuel, 'French gendarmes accused of keeping 'illegal ethnic lists of
} 
homelessness and subsequent deportation without individualised assessment, ${ }^{51}$ thus entailing a violation of the requisites for the expulsion of EU nationals (further explored below). Manuel Valls, the French Minister of the Interior at the time of the statement, did not hesitate to state that ' $[\mathrm{t}$ ]hose people [Roma migrants] have lifestyles that are extremely different from ours. For this reason, they should return to Romania or Bulgaria. ${ }^{52}$ Things do not appear to have changed at all in the meantime, as in 2014 a French police memo was leaked to the press which instructed officers to systematically identify Roma families living in the streets of an affluent Paris district and evict them. ${ }^{53}$ Although the memo was quickly corrected, the Minister of the Interior (Bernard Cazeneuve) still argued in favour of its legality, and the spokesman for President François Hollande (Stéphane Le Foll) echoed Valls’ words by saying that Roma should return to where they came from. ${ }^{54}$ An obvious message of cultural intolerance and socioeconomic segregation seems to guide political and police action, rather than an objective and sensible use of the existing legal framework (discussed in detail below).

Interestingly, in both France and Italy, events were mainly sparked by isolated incidents of a criminal nature (the shooting of a young Roma man in France and the alleged rape of a 14year-old girl by two Eastern European immigrants), ${ }^{55}$ and in both cases the subsequent

Roma’, The Telegraph, 7 October 2010; Franck Johannès, 'Le gouvernement embarrassé après la revelation d’un fichier illegal sur les Roms', Le Monde, 8 August 2010.

${ }^{51}$ European Association for the Defence of Human Rights, Roma evictions: the European Union is not respecting its commitments to human rights!, 11 September 2012, <http:/www.aedh.eu/plugins/fckeditor/userfiles/file/Communiqu\%C3\%A9s/Press\%20release\%20Roma\%20evi ctions\%2011_09\%20EN.pdf> accessed 30 March 2015; Martin, 'Expulsion of Roma; Amnesty International, Italy: Many children among dozens left homeless by forced eviction in Rome, $<$ http://www.amnesty.org/en/news/italy-many-children-among-dozens-left-homeless-forced-eviction-rome2014-07-09> accessed 30 March 2015; Amnesty International, “We ask for Justice”, pp. 15 ff; Human Rights Watch, France: Renewed Crackdown on Roma, 10 August 2012, <http://www.hrw.org/news/2012/08/10/francerenewed-crackdown-roma> accessed 30 March 2015.

${ }^{52}$ Translation in Amnesty International, “We ask for Justice”, p. 15. In French, 'Ce population ont des modes de vie extrêmement différent que le nôtre. (...) Pour cela, ils ont vocation à revenir en Roumanie ou Bulgarie’, France Inter, 'La question Rom dans le débat politique', 24 September 2013 (audio, at 90:10), <http://www.franceinter.fr/emission-le-79-la-question-rom-dans-le-debat-politique> accessed 30 March 2015. The original ‘ils ont vocation à revenir en Roumanie ou Bulgarie’ could, however, also be translated as 'are meant to return to Romania or Bulgaria'.

${ }^{53}$ Henry Samuel, 'Paris police order “systematic eviction” of Roma gypsies’, The Telegraph, 15 April 2014.

${ }^{54}$ Ibid.

55 Dwyer Arce, 'France president announces new measures against illegal Roma', Jurist, 29 July 2010; BBC, 'Troops patrol French village of Saint-Aignan after riot', 19 July 2010, <http://www.bbc.co.uk/news/world- 
reactions were utterly disproportionate. One may speculate that such strong reactions - both from private groups and the authorities - may be linked with extreme right-wing and racist discourses across Europe and the outset of the 2008 financial crisis. Accordingly, the Roma may have been seen as the ideal scapegoat for serious social frustrations and economic problems afflicting societies more generally. Such a 'diversion strategy' is all the more misdirected, as the latest economic crisis seems to have disproportionately affected the Roma minority. ${ }^{56}$

\section{The Roma and EU free movement of persons}

It has been wisely observed that 'the Roma with their nomadic tradition should fit perfectly within the paradigm of free movement, particularly since it is de-coupling from economic status' ${ }^{57}$ Indeed, as EU citizenship is based on a mobility paradigm, ${ }^{58}$ movement within and across national borders is a citizenship practice that would appeal to non-sedentary Roma communities. Yet the institutionalised paradigm of mobility is accompanied by structural (and socio-cultural) immobility. The Roma EU citizens have been amongst those most discouraged and prevented from enjoying that freedom. Although empirical research has revealed that the Roma wish to migrate especially to escape poverty and become economically independent through formal employment or self-sufficiency, ${ }^{59}$ public discourses still portray the Roma as wishing to depend on the welfare system and as undesirable members of society. The EU-

europe-10681796> accessed 30 March 2015. Also in Czech Republic and in Greece, isolated conflicts have been used as a pretext for large-scale reprisals against Roma communities: Amnesty International, "We ask for Justice", pp. 23.

${ }^{56}$ European Commission, Report on the implementation of the EU Framework for National Roma Integration Strategies.

${ }^{57}$ O'Nions, 'Roma expulsions and discrimination', 361.

${ }^{58}$ Dora Kostakopoulou, Citizenship, Identity and Immigration in the European Union: Between Past and Future (Manchester: Manchester University Press, 2001).

${ }^{59}$ EU Agency for Fundamental Rights, The situation of Roma EU citizens moving to and settling in other EU member states, November 2009, pp. 18-22. 
MIDIS (European Union Minorities and Discrimination Survey) revealed that the Roma are the most discriminated against group among those surveyed. The majority of the Roma in the Czech Republic (64\%), Hungary (62\%), Poland (59\%) and Greece (55\%) felt that they were discriminated against on the basis of their ethnicity at least once in twelve months. ${ }^{60}$ In addition, Roma respondents reported that they were relatively unaware of anti-discrimination laws and unlikely to report incidents of discrimination. ${ }^{61}$ Spatial segregation is frequent and in several Member States the respondents reported educational disadvantages. Furthermore, the survey indicated that Roma in most Member States predominantly do not travel and are likely to encounter profiling at border crossings when they return to their country of residence. ${ }^{62}$ This 'imposed' immobility contradicts the fundamental status of EU citizenship and the promotion of equal treatment throughout the EU.

The Court of Justice of the EU has been known for triggering a process of incremental, but transformative change, ${ }^{63}$ which has offered more protection to those EU citizens with fewer economic resources. Cases such as Baumbast ${ }^{64}$ and Grzelczyk $k^{65}$ have indicated the willingness of the Court to apply a very strict proportionality test to any limitation to free movement on the basis of limited economic resources or lack of health insurance. Although EU law on free movement of persons is far from being detached from any requirements concerning economic resources, and despite the lack of linearity of the Court's case law on this matter, it is possible to identify a trend - potentially supported by the EU Charter of Fundamental Rights, in particular its Title IV on solidarity - to increasingly protect the economically 'needy' EU

\footnotetext{
${ }^{60}$ EU-MIDIS, Main Results Report 2009, European Union Agency for Fundamental Rights, 2010, p. 155.

${ }^{61}$ Ibid, pp. 158-163.

62 Ibid, p. 173.

${ }^{63}$ T. Kostakopoulou, 'Ideas, Norms and European Citizenship: Explaining Institutional Change' (2005) 65(2) Modern Law Review 233-267.

${ }^{64}$ Case C-413/99, Baumbast, $R$ and Secretary of State for the Home Department, 17 September 2002, [2002] ECR I-07091.

65 Case C-184/99, Rudy Grzelczyk v. Centre public d'aide sociale d'Ottignies-Louvain-la-Neuve, 20 September 2001, [2001] ECR I-06193.
} 
citizen. ${ }^{66}$ One would think that this trend would support those Roma individuals wishing to improve their lives through migration within the EU. Instead, a significant proportion of those Roma individuals who have migrated have been effectively deprived of any benefits of their EU citizenship, especially free movement, both due to illegitimate, and often illegal, domestic measures and to the transitional periods that many Member States have implemented.

Owing to the transitional periods with regard to free movement of persons' provisions, citizens from Romania and Bulgaria only acquired full EU citizen status in many other EU Member States following the expiration of the final deadline of 31 December 2013. With regard to Croatia, a maximum transitional period of seven years applies, starting from 1 July 2013, i.e., until July 2020. Although these limitations have very limited numerical significance, their symbolic value cannot be ignored. All three countries have significant Roma minorities, which has, at least in the eyes of a large sector of public opinion, exacerbated the fear of an ‘immigration crisis’ or of a ‘jobs shortage’.

Public perceptions and social fears indeed play a key role in policy design and implementation at the EU and national levels. It has been noted that, in relation to the French context, the eviction and expulsion of a large number of Roma has occurred in the context of a 'complex and multilevel process of re-nationalisation and securitization [that] has taken place against the construction of the Roma as an internal threat, the erosion of the nation-state as a guarantor of universal rights, the decline of a centralised bureaucratic culture as well as the broader issue of the decline of sovereignty which call into question the natural order of the nation' ${ }^{67}$ In other words, to deal with a changing political, social and cultural landscape, political elites (especially Italian and French) have opted to use the Roma as ideal scapegoats

\footnotetext{
${ }^{66}$ Federico Forni, 'Free movement of “needy” citizens after the binding Charter: Solidarity for all?', in Giacomo Di Federico (ed.), The EU Charter of Fundamental Rights: From declaration to binding instrument (Springer, 2011), pp. 125-144.

${ }^{67}$ Marion Demossier, 'Sarkozy and the Roma Performing Securitization?’, UACES annual conference, Leeds, 2013.
} 
for any shortcomings of the state or policy deficiencies, and have recurrently portrayed Roma migrants as 'a threat to the fabric of society'. ${ }^{68}$ Securitisation efforts have gone as far as considering the mere existence of Roma camps around large cities as a serious social emergency capable of justifying a state of emergency for the period of a year, something that the European Parliament has considered worrying, inappropriate and disproportionate. ${ }^{69}$ The backlash that follows from such a trend is predictable: 'security measures increase ethnic tension by fuelling misconceptions and pandering to the extremist agenda' ${ }^{70}$

Such transitional periods and the securitisation discourses take place in the context of an already worrying lack of fully appropriate transposition of the Citizenship Directive across all EU Member States, in relation to which the Commission has expressed concern. ${ }^{71}$ With particular relevance for the Roma is the 'sufficient resources' requirement (Article 7(1)(b) of the Citizenship Directive). Indeed, as many Roma work in the informal economy, domestic authorities may more readily - and without the necessary procedural safeguards - hold them economically inactive, thus frustrating the Citizenship Directive’s aims. ${ }^{72}$ Another element of particular concern for the Roma is the submission of proof of residence: by requiring residence in an official type of housing, domestic authorities are effectively preventing camp dwellers including Roma - from proving their residence, thereby refusing them a residence permit when applicable. ${ }^{73}$ Such a transposition of the Citizenship Directive sidesteps cultural specificities and adopts an excessively restrictive interpretation of the Directive’s requirements.

\footnotetext{
${ }^{68}$ O'Nions, 'Roma expulsions and discrimination', 363; O. Parker, 'Roma and the Politics of EU Citizenship in France: Everyday Security and Resistance’ (2012) 50(3) Journal of Common Market Studies 475-491.

${ }^{69}$ European Parliament resolution of 10 July 2008 on the census of the Roma on the basis of ethnicity in Italy, paras. 9 and 10.

${ }^{70}$ O'Nions, 'Roma expulsions and discrimination', 377.

${ }^{71}$ European Commission, Report from the Commission to the European Parliament and the Council on the application of Directive 2004/38/EC on the right of citizens of the Union and their family members to move and reside freely within the territory of the Member States, COM(2008) 840 final, Brussels, 10 December2008.

72 Nial O’Higgins and Andrey Ivanov, 'Education and employment opportunities for the Roma' (2006) 48 Comparative Economic Studies 6-19.

73 O’Nions, ‘Roma expulsions and discrimination', 380.
} 
A broader free movement issue aligned with legitimate concerns about respect for cultural differences concerns the availability of caravan sites. Although there is legislation in several EU Member States imposing on public authorities the obligation to make a sufficient number of sites available, ${ }^{74}$ there are numerous instances of judicial litigation regarding the inadequate provision of such sites. ${ }^{75}$ Despite the fact that this matter can be seen to fall within the scope of EU law as it is, for all purposes, a free movement issue (as the lack of available sites prevents the free movement of nomadic Roma), the EU has yet to intervene in this matter. Commissioner Reding has expressed the view that this is a 'purely internal situation' ${ }^{76}$ Critics might argue that the EU lacks competence on urban planning matters. This, however, has not prevented the Parliament from calling on Member States to 'use urban planning for integration and de-segregation, and to develop the infrastructural and environmental qualities of the cities most markedly affected by social imbalances’. ${ }^{77}$

The matter of greater concern for Roma EU citizens, however, remains the scope for derogations of free movement and the possibility of expulsion from EU Member States, as acutely illustrated by the French, Italian and other cases discussed above.

4. Scope for derogating from free movement and its impact on the Roma

\footnotetext{
${ }^{74}$ For example, in France, Loi n $2000-614$ du 5 juillet 2000 relative à l'accueil et à l'habitat des gens du voyage (the Besson Act, consolidated version of 28 December 2007).

${ }^{75}$ See, for example, the following cases heard by the European Court of Human Rights, all concerning the UK: Buckley v. United Kingdom, 29 September 1996, Application No. 20348/92, 23 EHRR 101; Varey v. United Kingdom, $21 \quad$ December $2000, \quad$ Application $\quad$ No. $26662 / 95$ <http://hudoc.echr.coe.int/sites/eng/pages/search.aspx?i=001-59103>; Lee v. United Kingdom, 18 January 2001, Application No. 25289/94 <http://hudoc.echr.coe.int/sites/eng/pages/search.aspx?i=001-59157>; Chapman v. United Kingdom, 18 January 2001, Application No. 27238/95, 33 EHRR 18; Coster v. United Kingdom, 18 January 2001, Application No. 24876/94 <http://hudoc.echr.coe.int/sites/eng/pages/search.aspx?i=001-59156>; Beard v. United Kingdom, 18 January 2001, Application No. 24882/94 $<$ http://hudoc.echr.coe.int/sites/eng/pages/search.aspx?i=001-59155>; Jane Smith v. United Kingdom, 18 January 2001, No. 25154/94 <http://hudoc.echr.coe.int/sites/eng/pages/search.aspx?i=001-59158>; all accessed 30 March 2015.

${ }^{76}$ This was stated in an interview which Commissioner Reding gave to Le Monde in September 2012 and is cited in S. Carrera, 'The Framing of the Roma as Abnormal EU Citizens', in E. Guild, C. Gortazar Rotaeche and D. Kostakopoulou (eds.), The Reconceptualisation of EU Citizenship (Martinus Nijhoff, 2014), p. 33.

${ }^{77}$ European Parliament resolution of 12 December 2013 on the progress made in the implementation of the National Roma Integration Strategies, P7_TA-PROV(2013)0594, para 20.
} 
While the fundamental rights to free movement and residence have had an empowering effect on EU citizens and have led the Member States to concede that internal mobility has positive effects, the power of Member States to derogate from these rights still raises concerns amongst EU and non-EU citizens, of Roma and non-Roma origin. In the post-2008 era an increasing reliance on the legal grounds available under EU law in order to restrict free movement and order the expulsion of EU citizens from the host Member State can be observed. The exercise of this power has a markedly negative impact on the lives of the individuals affected and their families, friends and employers. EU citizens are precluded from enjoying the benefits of associated action and from making choices about their lives, and may face deportation from a Member State which has been their 'home' for an extended period of time. For these reasons, EU law has always circumscribed the Member States' sovereign power by limiting it to public policy, public security and public health considerations, and to cases of fraud and abuse of law (see, for example, Chapter VI and Article 35 of the Citizenship Directive).

The development of EU citizenship also exerts a limiting effect on the Member States’ powers to order the expulsion of an EU citizen. It has always been the case that Member States do not have to observe the principle of non-discrimination on the ground of nationality (Article 18 TFEU) in this area, since they can expel citizens from other EU Member States but cannot expel their own nationals. However, this may be seen as a rather anachronistic power in the light of the evolution of EU citizenship and its transformation into a fundamental status. An argument can thus be made on normative grounds for reducing the scope of the derogations to a certain extent. ${ }^{78}$ Would it perhaps not be more appropriate to simply treat any 'EU foreigners'

\footnotetext{
${ }^{78}$ P. Icard, 'La citoyenneté européenne altérée: L'expulsion pour atteinte à l'ordre et à la sécurité publics', in P. Icard (ed.), Une citoyenneté européenne dans tous ses «États» (Éd. universitaires de Dijon, 2009), pp. 59-85, at p. 64; T. Kostakopoulou and N. Ferreira, 'Testing Liberal Norms: The Public Policy and Public Security Derogations and the Cracks in European Union Citizenship’ (2014) 20(3) Columbia Journal of European Law 167-191.
} 
as a Member State's own nationals, that is, subject them to criminal and other sanctions for their conduct, but not to 'exclusion orders'? Of course, the political reality in the post-2008 era displays the opposite trend: certain Member States are keen to increase the scope of the derogations, treat EU citizens as 'threats' to the security of society, and introduce legislative provisions that contradict the Citizenship Directive.

Although the abolition of obstacles to the free movement of workers was, from early on, a priority of the Community institutions and Member States, the intention of reserving a different treatment for citizens from other Member States was also clear from the start. The rules on derogating from free movement and possibly expelling citizens from other Member States were soon enshrined statutorily: the derogation grounds should not be invoked to serve economic ends, any measures taken on public policy or public security grounds should be based exclusively on the personal conduct of the individual concerned, past criminal convictions should not suffice as grounds to take such measures, and the violation of formal requirements should generally not be invoked to create an obstacle to free movement. ${ }^{79}$ This set of rules was overall interpreted generously by the Community Court in an important line of case law, beginning with Van Duyn ${ }^{80}$ and including Donatella Calfa ${ }^{81}$ where it was stated that, despite Member States possessing some discretion on this matter, the public policy ground should be interpreted restrictively and its application subjected to Community control. The 'personal conduct' requirement was interpreted in Bonsignore ${ }^{82}$ as precluding 'general prevention' objectives, and the importance of procedural safeguards was highlighted in Rutili. ${ }^{83}$ Also, in

\footnotetext{
${ }^{79}$ Council Directive 64/221/EEC of 25 February 1964 on the co-ordination of special measures concerning the movement and residence of foreign nationals which are justified on grounds of public policy, public security or public health.

${ }^{80}$ Case 41/74, Yvonne van Duyn v. Home Office, Judgment of 4 December 1974, [1974] ECR 01337.

${ }^{81}$ Case C-348/96, Criminal proceedings against Donatella Calfa, Judgment of 19 January 1999, [1999] ECR I00011.

${ }^{82}$ Case 67/74, Carmelo Angelo Bonsignore v. Oberstadtdirektor der Stadt Köln, Judgment of 26 February 1975, [1975] ECR 00297.

${ }^{83}$ Case 36/75, Roland Rutili v. Ministre de l'intérieur, Judgment of 28 October 1975, [1975] ECR 01219.
} 
Royer, ${ }^{84}$ Pieck $^{85}$ and $M R A X,{ }^{86}$ the Court made sure that the violation of formalities was not used as grounds for expulsion or impeding entrance into a Member State's territory, and in Bouchereau $^{87}$ and Commission $v$ Netherlands ${ }^{88}$ the Court reinforced the idea that past criminal convictions could not in themselves constitute grounds for expulsion. Member States have also been prevented from using the derogation grounds with the intention of excluding foreign workers from certain economic sectors through the decisions in $G \ddot{u} l^{89}$ and Anker. ${ }^{90}$ Finally, in Cornuaille ${ }^{91}$ and Commission v. Germany, ${ }^{92}$ the Court required some degree of consistency in relation to the measures taken in similar circumstances vis-à-vis both a Member State's own citizens and citizens from other Member States.

The principle of proportionality has remained an important tool, as seen in Baumbast, ${ }^{93}$ Derin $^{94}$ and Huber. ${ }^{95}$ Most importantly, the strengthening of the fundamental rights discourse at the Community level, following the introduction of Article 6 TEU and the adoption of the Charter of Fundamental Rights, also had a positive impact on the interpretation of the derogation grounds. The Court has clearly re-shifted the focus of its analysis in some cases, by considering in detail the impact that an expulsion order can have on the fundamental rights of

\footnotetext{
${ }^{84}$ Case 48/75, Jean Noël Royer, Judgment of 8 April 1976, [1976] ECR 00497.

${ }^{85}$ Case 157/79, Regina v. Stanislaus Pieck, Judgment of 3 July 1980, [1980] ECR 02171.

${ }^{86}$ Case C-459/99, Mouvement contre le racisme, l'antisémitisme et la xénophobie ASBL (MRAX) v. État belge, Judgment of 25 July 2002, [2002] ECR I-06591.

${ }^{87}$ Case 30/77, Régina v. Pierre Bouchereau, Judgment of 27 October 1977, [1977] ECR 01999.

${ }^{88}$ Case C-50/06, Commission v. Netherlands, Judgment of 7 June 2007, [2007] ECR I-04383.

${ }^{89}$ Case 131/85, Emir Gül v. Regierungspräsident Düsseldorf, Judgment of 7 May 1986, [1986] ECR 01573.

90 Case C-47/02, Albert Anker, Klaas Ras, Albertus Snoek v. Bundesrepublik Deutschland, Judgment of 30 September 2003, [2003] ECR I-10447.

${ }^{91}$ Cases 115 and 116/81, Rezguia Adoui v. Belgian State and City of Liège; Dominique Cornuaille v. Belgian State, Judgment of 18 May 1982, [1982] ECR 01665.

92 Case 249/86, Commission v. Germany, Judgment of 18 May 1986, [1989] ECR 01263.

${ }^{93}$ Case C-413/99, Baumbast, R and Secretary of State for the Home Department, Judgment of 17 September 2002, [2002] ECR I-07091.

${ }^{94}$ Case C-325/05, Ismail Derin v. Landkreis Darmstadt-Dieburg, Judgment of 18 July 2007, [2007] ECR I-06495.

${ }^{95}$ Case C-524/06, Heinz Huber v. Bundesrepublik Deutschland, Judgment of 16 December 2008, [2008] ECR I09705.
} 
the individual in question. In Orfanopoulos ${ }^{96}$ and Aikrich $^{97}$ for example, the Court reached decisions which were in line with past jurisprudence, but did so by resorting to a fundamental rights discourse, especially the right to private and family life. This has followed from looking at free movement as a fundamental right more generally, in relation to both nationals of Member States and their family members, as in Diatta. ${ }^{98}$ The Citizenship Directive has reflected this fundamental rights discourse, in particular with regard to children, something already strongly asserted in Baumbast. ${ }^{99}$ Indeed, children cannot be expelled if expulsion is not in their best interests, unless it is justifiable on imperative grounds of public security (Consideration No. 24 Preamble and Article 28(3) of the Citizenship Directive), a positive influence of the human rights discourse and children's rights instruments in particular. ${ }^{100}$ In addition, the creation of EU citizenship by the Treaty of Maastricht (which entered into force on 1 November 1993) and its subsequent jurisprudential development have contributed to a stronger rhetoric supporting the right of EU citizens and their families to be protected from expulsion or, more generally, from obstacles to free movement. This can be seen in the Court's references to EU citizenship to substantiate the reasoning in its decisions, such as in

\footnotetext{
${ }^{96}$ Cases C-482/01 and C-493/01, Georgios Orfanopoulos, Natascha Orfanopoulos, Melina Orfanopoulos, Sofia Orfanopoulos and Land Baden-Württemberg (C-482/01), and between Raffaele Oliveri and Land BadenWürttemberg (C-493/01), Judgment of 29 April 2004, [2004] ECR I-05257.

${ }_{97}$ Case C-109/01, Secretary of State for the Home Department and Hacene Akrich, Judgment of 23 September 2003, [2003] ECR I-09607.

${ }^{98}$ Case 267/83, Aissatou Diatta v. Land Berlin, Judgment of 13 February 1985, [1985] ECR 00567, paragraph 13 (in reference to the Commission's submission). See also, Joseph H. H. Weiler, 'Thou Shalt Not Oppress a Stranger: On the Judicial Protection of the Human Rights of Non-EC Nationals - A Critique' (1992) 3(1) European Journal of International Law 65-91.

${ }^{99}$ Case C-413/99, Baumbast, R and Secretary of State for the Home Department, Judgment of 17 September 2002, [2002] ECR I-07091.

${ }^{100}$ Helen Stalford and Eleanor Drywood, 'Using the CRC to Inform EU law and Policy-making', in Antonella Invernizzi and Jane Williams (eds.), The Human Rights of Children: From Visions to Implementation (Ashgate, 2011), pp. 199-218, at p. 206.
} 
Carpenter, ${ }^{101}$ Baumbast, ${ }^{102}$ Chen $^{103}$ and Jipa,${ }^{104}$ often also favouring EU citizens’ family members without EU citizenship. This evolution has led the Commission to summarise the current state-of-affairs by stating that 'the [Citizenship] Directive must be interpreted and applied in accordance with fundamental rights, in particular the right to respect for private and family life, the principle of non-discrimination, the rights of the child and the right to an effective remedy as guaranteed in the European Convention of Human Rights (ECHR) and as reflected in the EU Charter of Fundamental Rights ${ }^{305}$ (footnotes omitted). It has thus been argued that the confluence of arguments based on proportionality, fundamental rights and citizenship offers a 'formidable pooled shield against which Member States are (almost always) powerless’ ${ }^{106}$

From this, one can conclude that there is a consistent line of EU case law supporting a rights-based approach to protect individuals' interests. Illustrative of this is also the fact that, in a sample of 30 cases of free movement of persons ranging from the 1970s until the 2000s, the Court has not allowed the use of the derogation ground in $80 \%$ of them (24), having found the use of the derogation ground legitimate only in $10 \%$ of the cases (three) and having left the outcome to be decided by the domestic court in the remaining $10 \%$ (three). Public policy is undoubtedly the most commonly used derogation ground (60\% of the cases, 18 out of 30), a reflection of how attractive this potentially broad notion is to Member States. This is followed

\footnotetext{
101 Case C-60/00, Mary Carpenter v. Secretary of State for the Home Department, Judgment of 11 July 2002 , [2002] ECR I-06279.

102 Case C-413/99, Baumbast, $R$ and Secretary of State for the Home Department, Judgment of 17 September 2002, [2002] ECR I-07091.

103 Case C-200/02, Kunqian Catherine Zhu and Man Lavette Chen v. Secretary of State for the Home Department, Judgment of 19 October 2004, [2004] ECR I-09925.

104 Case C-33/07, Ministerul Administraţiei şi Internelor - Direcţia Generală de Paşapoarte Bucureşti v. Gheorghe Jipa, Judgment of 10 July 2008, [2008] ECR I-05157.

${ }^{105}$ European Commission, Communication from the Commission to the European Parliament and the Council on guidance for better transposition and application of Directive 2004/38/EC on the right of citizens of the Union and their family members to move and reside freely within the territory of the Member States, COM(2009) 313 final, Brussels, 2 July 2009, p. 3.

${ }^{106}$ Niamh Nic Shuibhne, 'Derogating from the free movement of persons: When can EU citizens be deported?' (2006) Cambridge Yearbook of European Legal Studies 8, 187-227, at 188.
} 
by the use of a mix of grounds in $20 \%$ of the cases (six), which indicates that decisions could be more precise in the identification and conceptualisation of the derogation ground(s) in question. Indeed, the border between the notions of 'public policy' and 'public security' has never been sufficiently clarified and remains blurred. ${ }^{107}$

The Citizenship Directive has strengthened the legal status of EU citizens and their families exercising their right to free movement, namely by obliging Member States to consider a range of factors before issuing an expulsion order (including duration of residence, age, state of health, family and economic situation, degree of integration in the host Member State and links with Member State of origin; Article 28(1)). In addition, individuals with a permanent residence status may only be expelled on 'serious grounds of public policy and public security' (Article 28(2)) and, in the case of residence for at least 10 years, 'imperative grounds of public security' are required (Article 28(3)). ${ }^{108}$ The terms 'serious grounds of public policy' and ‘imperative grounds of public security' have not been defined by the Citizenship Directive, thereby leading the European Commission to issue guidelines and the Court of Justice of the EU to operationalise them in the first cases that reached it. ${ }^{109}$ While the Commission sought to differentiate between the two grounds, thereby confining public policy to disturbances of social order, on the one hand, and public security to internal or external security threats, on the other, the Court deviated from this guidance. ${ }^{110}$ In both Tsakouridis and Pietro Infusino, the Court blurred the distinction between public policy and public security by extending the scope of Article 28(3) of the Citizenship Directive to criminal offences 'that might pose a direct threat

\footnotetext{
${ }^{107}$ For example, Case C-145/09, Land Baden-Württemberg v. Panagiotis Tsakouridis, Judgment of 23 November 2010, [2010] ECR I-11979.

108 The Commission's original proposal, however, went further than this and precluded the possibility of expelling on grounds of public policy or public security EU citizens or their family members, irrespective of nationality, who had the right of permanent residence, or family members who were minors, a proposal rejected by the Council: European Commission, Proposal for a European Parliament and Council Directive on the right of citizens of the Union and their family members to move and reside freely within the territory of the Member States, COM(2001) 257 final, Brussels, 23 May 2001, p. 42 (Article 26(2)).

${ }^{109}$ Kostakopoulou and Ferreira, 'Testing Liberal Norms'.

${ }^{110}$ European Commission, Communication from the Commission to the European Parliament and the Council on guidance for better transposition and application of Directive 2004/38/EC, p. 10.
} 
to the calm and physical security of the population'. ${ }^{111}$ Serious criminality can thus activate the application of Article 28(3) and Member States remain free to categorise conduct as contrary to public security according to the particular values in their domestic legal order. ${ }^{112}$ Trafficking in narcotics as part of an organised group and the sexual exploitation of children have been seen to fall within the scope of 'imperative grounds of public security' in Tsakouridis and Pietro Infusino respectively. ${ }^{113}$ Notably, the reference to 'the calm and physical security of the population' is an interpretive innovation which undermines the rationale of the Citizenship Directive, while the reference to the 'particular values of the legal order of the Member States' creates legal uncertainty, as it is bound to lead to divergent interpretations and thus to the unequal treatment of long-term resident EU citizens throughout the European Union. ${ }^{114}$

Although the strong line of case law protecting individuals' rights from the arbitrary exercise of Member States’ powers and the comprehensive and generous wording of Articles 27-33 of the Citizenship Directive would appear to offer EU citizens and their families reasons to believe that their expulsion from a host EU Member State may only occur in extreme circumstances, recent developments suggest that this may be an excessively optimistic conclusion. As the French and Italian events show and as Nic Shuibhne rightly observes, 'it can hardly be said that Member States no longer attempt to remove EU citizens from their territories; on the contrary, this seems still to happen with fairly striking frequency’. ${ }^{115}$ This

\footnotetext{
${ }^{111}$ Case C-145/09, Land Baden-Württemberg v. Panagiotis Tsakouridis, Judgment of 23 November 2010, [2010] ECR I-11979; and Case C-348/09, Pietro Infusino v. Oberburgermeisterin der Stadt Remscheid, Judgment of 22 May 2012, 2012 ECJ EUR-Lex LEXIS 843 (2012).

112 Case C-348/09, Pietro Infusino v. Oberburgermeisterin der Stadt Remscheid, Judgment of 22 May 2012, 2012 ECJ EUR-Lex LEXIS 843 (2012), at para. 29.

${ }^{113}$ Case C-145/09, Land Baden-Württemberg v. Panagiotis Tsakouridis, Judgment of 23 November 2010, [2010] ECR I-11979; and Case C-348/09, Pietro Infusino v. Oberburgermeisterin der Stadt Remscheid, Judgment of 22 May 2012, 2012 ECJ EUR-Lex LEXIS 843 (2012).

114 Kostakopoulou and Ferreira, 'Testing Liberal Norms' 174-5. For commentary on Pietro Infusino, see L. Azoulai and S. Coutts, 'Restricting Union Citizens' Residence Rights on Grounds of Public Security. Where Union Citizenship and the AFSJ Meet: PI' (2013) 50 Common Market Law Review 553; D. Kochenov and B. Pirker, 'Deporting EU Citizens: A Counter-Intuitive Trend' (2013) 19 Columbia Journal of European Law 369391.

${ }^{115}$ Nic Shuibhne, 'Derogating from the free movement of persons', at 188.
} 
can be particularly dangerous when, with the excuse of insanitary living conditions and under the cover of 'voluntary return', EU citizens are threatened with eviction and offered no housing alternative - with such measures not being technically considered 'deportation orders', authorities escape the legal obligation of respecting the requisites which the expulsion of EU citizens must fulfil. ${ }^{116}$ In addition, the cases mentioned above have made substantial concessions to Member States' discretion and securitisation agendas, ${ }^{117}$ and (even if subject to the principle of proportionality) the lack of sufficient resources and comprehensive sickness insurance has effectively worked as a fourth derogation ground all along. ${ }^{118}$

As noted in Section 2 above, EU citizens of Romania and Bulgaria belonging to the Roma minority were expelled in 2010 from settlements in France and were then served with an expulsion order. In an attempt to facilitate the removal of those people, the French authorities offered financial incentives such as $€ 300$ per adult and $€ 100$ per child before repatriating them to Romania. ${ }^{119}$ Following widespread criticism, France adopted Law 2011672 on Immigration, Integration and Nationality, ${ }^{120}$ but arguably several provisions of this legislation fall short of the requirements of the Citizenship Directive. For example, unauthorised occupation or settlement and stealing from landfill sites can activate the application of the public policy derogation, while expulsion can follow a suspected violation of French labour law. Similarly, a mere suspicion that a Roma EU citizen resides in France with the intention of relying on the French welfare system for support could lead to an expulsion order, thereby contravening both Article 14(3) of the Citizenship Directive, which states that 'an expulsion measure shall not be the automatic consequence of a Union citizens' or his or her family member's recourse to the social assistance system of the host Member

\footnotetext{
${ }^{116}$ Martin, Expulsion of Roma.

117 See Case C-348/09, Pietro Infusino v. Oberburgermeisterin der Stadt Remscheid, Judgment of 22 May 2012, 2012 ECJ EUR-Lex LEXIS 843 (2012).

118 Nic Shuibhne, 'Derogating from the free movement of persons', at 208-223.

119 The repatriation was carried out by the Office Francais de l'immigration et de l'integration.

120 Journal Officiel de la Republique Francaise, 2011, Loi no 2011-672 du 16 Juin 2011.
} 
State', and also the existing case law which requires an examination of the personal circumstances of the individual concerned. ${ }^{121}$

Consequently, the principle of non-discrimination on grounds of nationality remains vulnerable and is seriously curtailed by the possibility of expulsion. Furthermore, the 'formidable pooled shield'122 of proportionality, fundamental rights and citizenship has not been working in favour of Roma, not even of Roma children, as the collective expulsion of Roma by several EU Member States has not been subjected to the required individual assessment and procedural safeguards. The EU Charter of Fundamental Rights clearly prohibits both discrimination on the basis of membership of a national minority (Article 21) and also collective expulsions (Article 19). ${ }^{123}$ It also reinforces EU citizens’ rights (Article 45). Yet, neither the Treaty on the Functioning of the EU nor the Charter can prevent the creation of hierarchical statuses within the institution of EU citizenship and the relegation of the Roma EU citizens to a second-class status owing to the discriminatory practices and discourses of national authorities. $^{124}$

Interestingly, the European Social Charter was invoked by the European Committee of Social Rights of the Council of Europe, which held that the French policy of forced evictions of Roma EU citizens violated the European Social Charter as the policy was indirectly discriminatory and inconsistent with respect for human dignity. ${ }^{125}$ It is also important to recall that the events affecting the residence of the Roma in France, as well as in Italy, raise equally serious concerns from an international law perspective. Indeed, although the Citizenship Directive may seem the most obvious legal basis to defend the legal right of Roma EU citizens

\footnotetext{
121 Case 30/77, Régina v. Pierre Bouchereau, Judgment of 27 October 1977, [1977] ECR 01999.

122 Nic Shuibhne, 'Derogating from the free movement of persons', at 188.

${ }^{123}$ European Commission, 2012 Report on the Application of the EU Charter of Fundamental Rights, COM(2013) 271 final, Brussels, 8 May 2013.

${ }^{124}$ See C. Aradau, J. Huysmans, P. G. Macioti and V. Squire, 'Mobility interrogating free movement: Roma Acts of European Citizenship’, in E. F. Isin and M. Saward (eds.), Enacting EU Citizenship (Cambridge University Press, 2013), pp. 132-54.

125 Centre on Housing Rights and Evictions (COHRE) v. France (Complaint No 63/2010, decision on the merits of 28 June 2011, paras. 35-55).
} 
to residence in EU Member States, the international legal framework also offers important legal tools in this context, in particular for the non-EU citizens of Roma origin. Article 5(d)(I) and (II) of the International Convention on the Elimination of All Forms of Racial Discrimination establishes the freedom of movement within and beyond a state’s borders; ${ }^{126}$ Article 22 of the International Convention on the Protection of the Rights of All Migrant Workers and Members of Their Families establishes that migrant workers and their families must not be subjected to measures of collective expulsion; ${ }^{127}$ and Article 4 of Protocol No. 4 to the ECHR expressly prohibits the collective expulsions of foreigners. ${ }^{128}$ In addition, any migration-related measure is subject to Article 14 ECHR in conjunction with other ECHR norms. These norms bind all EU Member States, with the exception of Protocol No. 4 to the ECHR with regard to Greece and the UK. These international legal norms, coupled with the EU law framework, should offer a sufficiently strong safety net to prevent collective expulsions and discriminatory treatment of Roma migrants. If these illicit actions continue to take place, it is surely not due to the lack of legal tools, but rather to deficient enforcement and limited political will. This deficiency again ultimately highlights a serious lack of humaneness in the approach taken by the EU's Roma law and policy.

5. EU citizenship beyond free movement

Albeit arguably the central entitlement, free movement is but one of the rights that are attached to EU citizenship status. The rights to be elected and elect representatives for local and

\footnotetext{
${ }^{126}$ Adopted and opened for signature and ratification by General Assembly resolution 2106 (XX) of 21 December 1965, and entered into force on 4 January 1969.

127 Adopted and opened for signature and ratification by General Assembly resolution 45/158 of 18 December 1990, and entered into force on 1 July 2003.

${ }^{128}$ Protocol No. 4 to the Convention for the Protection of Human Rights and Fundamental Freedoms, securing certain rights and freedoms other than those already included in the Convention and in the first Protocol thereto as amended by Protocol No. 11, Strasbourg, 16 September 1963.
} 
European elections, to diplomatic protection, to petition the European Parliament, address EU institutions, and submit a complaint to the EU Ombudsman (Article 20 TFEU), are also constitutive of this status, thus the participatory dimension of citizenship is also deserving of some attention in the context of this discussion. This dimension was, to some extent, acknowledged by Decision 1093/2012, ${ }^{129}$ which designated 2013 as the European Year of Citizens. Indeed, Article 2(1) of this Decision determined that 'the European Year of Citizens [should] also promote the enjoyment by Union citizens of the other rights [besides the right to move and reside freely within the territory of the Member State] attached to Union citizenship', and Recital 3 also highlighted how the Stockholm Programme promoted the 'rights which allow Union citizens to participate actively in the democratic life of the Union'. Moreover, Article 3 of the same Decision indicates that the objectives of the European Year of Citizens can be achieved, amongst other, through: information, media coverage, education and awareness-raising campaigns; conferences, hearings and other events; multilingual participatory tools, including direct democracy tools as the citizens' initiative and public consultations; and strengthening existing tools such as Europe Direct and SOLVIT. Yet, even in this Decision one can see a clear bias towards free movement rights and insufficient attention to the participatory dimension of EU citizenship. ${ }^{130}$ This is inappropriate in the light of the democratic concerns that underpinned the establishment of the EU citizenship status and the gradual liberation of this status from 'market integration' discourses by scholars and judges alike. $^{131}$

\footnotetext{
${ }^{129}$ Decision No 1093/2012/EU of the European Parliament and of the Council of 21 November 2012 on the European Year of Citizens (2013), OJ L 325/1, 23 November 2012.

130 Nikos Vogiatzis, ‘A “European Year of Citizens”? Looking Beyond Decision 1093/2012: Eyeing the European Elections of 2014’ (2014) 15(4) Perspectives on European Politics and Society 571-588.

${ }^{131}$ Ibid, 574 ff; Niamh Nic Shuibhne 'The Resilience of EU Market Citizenship' (2010) 47(6) Common Market Law Review 1597-1628.
} 
Following the lead of the Council of Europe on the participatory dimension of citizenship, ${ }^{132}$ the EU has acknowledged that the inclusion of the Roma in the EU Member States requires a commitment to removing structural inequalities in the fields of employment, education, housing and health and to empowering the members of the Roma communities. The European Parliament, in particular, has highlighted the need to enhance the Roma's active citizenship, involvement in public and political life, and associative and political representation at regional, national and EU level. ${ }^{133}$ Besides the European Parliament, ${ }^{134}$ the Commission has also recognised that effective participation and consultation is one of four 'success factors' for Roma inclusion strategies ${ }^{135}$ and has invited the Member States to build national strategies for the integration of EU citizens of Roma origin. These strategies should include clear goals and indicators as well as a special focus on funding. The Commission has subsequently evaluated the extent to which structural requirements and funding were addressed in national Roma integration strategies. ${ }^{136}$ As the Commission stated, 'better integration of Roma is therefore a moral and an economic imperative' and the Member States have clear responsibilities in this area. ${ }^{137}$ Education, health, employment and housing are seen as important policy priorities for making the inclusion of the Roma a reality in the Member States.

Enhancing civil participation is one of the key aspects of the EU Framework for National Roma Integration Strategies, ${ }^{138}$ and ensuring the active participation of the Roma communities is seen to be important in facilitating Roma integration in the EU. Roma and pro-

\footnotetext{
${ }^{132}$ Recommendation CM/Rec(2008)5 of the Committee of Ministers to member states on policies for Roma and/or Travellers in Europe (adopted by the Committee of Ministers on 20 February 2008 at the 1018th meeting of the Ministers' Deputies), sections III.iii, III.iv and V.3.i.

${ }^{133}$ European Parliament resolution of 9 March 2011 on the EU strategy on Roma inclusion (2010/2276 (INI)), paras. 4(c), 12, 22, 23, 79.

${ }^{134}$ Ibid, para. 4(a).

${ }^{135}$ European Commission, Roma Integration: First Findings of Roma Task Force and Report on Social Inclusion, MEMO/10/701, Brussels, 21 December 2010.

136 European Commission, National Roma Integration Strategies: A First Step in the Implementation of the EU Framework, COM(2012) 226 final, Brussels, 21 May 2012.

137 Ibid, p. 2.

${ }^{138}$ European Commission, An EU Framework for National Roma Integration Strategies up to 2020.
} 
Roma civil society organisations are encouraged to play a proactive role and to engage in a continuous dialogue with EU institutions and national authorities. They have been invited to play an active role in implementing and monitoring national strategies, but this requirement has not been fulfilled yet. Austria and Spain have consulted Roma civil society on the implementation of their national strategies, ${ }^{139}$ while Finland has introduced such a consultation via the Regional Advisory Boards of Romani Affairs. ${ }^{140}$ Civil Society awards to organisations working on Roma inclusion were made on 1 October 2014 by the European Commission and endowed by the European Economic and Social Committee. The EU’s Cohesion Policy 20142020 regulations provided a positive platform in this respect and highlight the EU's sustained commitment to facilitating the inclusion of the Roma communities in European societies. ${ }^{141}$ Grassroots organisations, on the other hand, are keen to highlight the importance of a 'Romaled ${ }^{142}$ strategy of inclusion and change centred on three main principles: community capacitybuilding, structured dialogue and simplification of access to funding mechanisms at the local level. ${ }^{143}$

In addition to promoting an active Roma civil society, a key dimension of effective inclusion is the political participation of the Roma through the political and electoral system (Article 3 of Protocol No. 1 to ECHR). ${ }^{144}$ Still, there is much more to civil participation than strictly political participation; a much broader, richer notion can be envisaged, one including participation in public debates and associative life. Again, this can be supported by a fundamental rights framework (Articles 10 and 11 ECHR), but much more than that needs to be put in place to ensure that Roma communities and individuals are able to participate in the

\footnotetext{
${ }^{139}$ Fundamental Rights Agency, Fundamental Rights: Challenges and Achievements in 2013 - Annual Report (Publications Office of the European Union, 2014), p. 171.

140 Ibid.

141 These were published in the Official Journal on 20 December 2013 (L. 347).

142 Z. Jovanovic, Investing in a Roma-led Change (Open Society Foundations - Roma Initiative Office, 2014).

143 See S. D’Agostino, 'The Missing Piece: Empowerment of Roma Grassroots Organisations in EU Roma Integration Policies’, Policy Brief, Institute for European Studies, Issue 2014/10, December 2014, p. 4.

144 Protocol to the Convention for the Protection of Human Rights and Fundamental Freedoms as amended by Protocol No. 11, Paris, 20 March 1952.
} 
public life of the societies within which they live, in a way commensurate with their EU citizenship status.

Ensuring the equal treatment of Roma with respect to access to the labour market and to employment opportunities remains a key priority, and the national integration plans of several Member States, such as Germany, Austria, Belgium, Croatia, France, Portugal, Poland and Slovenia, included a number of initiatives and training programmes designed to promote capability building. ${ }^{145}$ Although this is important, a more sustained and multifaceted approach tackling structural discrimination and segregation in education in several Member States is needed. The European Court of Human Rights condemned the placing of two Roma boys in schools for people with intellectual impairment in Horvath and Kiss v. Hungary and raised the question whether their integration might have been compromised as a result of the placement. ${ }^{146}$ Both the ECHR's protection of the right of education (Article 2 of Protocol 1) and the prohibition of discrimination (Article 14) had not been respected by the Hungarian government, but judicial condemnation alone is not sufficient to end the common practice of placing Roma children in schools for persons with learning difficulties. The same applies to the practice of establishing Roma 'special schools' which essentially institutionalise segregation ${ }^{147}$ and more often than not provide an inferior standard of education. ${ }^{148}$ Discrimination in housing and in employment, forced evictions, the ghettoisation of the Roma within municipalities and poor living standards, all contribute to creating inhumane conditions for everyday living. The regression into depths of inhumanity is aided by racism, antiGypsyism, negative media representations and official discourses linking Roma to criminality. Overcoming inhumanity or defending the humane in this respect will not be the result of

\footnotetext{
${ }^{145}$ Fundamental Rights, n 141 above, p. 170-171.

${ }^{146}$ European Court of Human Rights, Horvath and Kiss v. Hungary, 29 January 2013, Application No. 11146/11. ${ }^{147}$ See European Court of Human Rights, Lavida and Others v. Greece, 30 May 2013, Application No. 7973/10. ${ }^{148}$ Fundamental Rights Agency, Fundamental Rights, p. 175.
} 
humanitarian action and initiatives, but of asserting the Roma’s citizenship status, both national and EU-based, and promoting their empowerment.

\section{Conclusion}

Human beings cannot flourish in constricted, uncongenial and discriminatory social settings. The ambivalence of EU citizenship lies in the fact that, although it has empowered individuals to contemplate and actualise life horizons beyond the borders of their states, it has not managed to reduce structural inequalities more generally, or minority discrimination.

Although there has been a renewed commitment since 2010 on the part of the European institutions to address the problems facing the Roma, a more coordinated and multi-stakeholder approach is needed in order to ensure the effective exercise of free movement and other rights associated with EU citizenship status, and to bring about any significant and substantive changes in the lives of marginalised social groups. The European Roma Platform, despite constituting a valuable EU forum, has not yet ensured this. The way forward to ensure a more humane treatment of Roma in the context of free movement and EU citizenship more generally may lie in a combination of stricter rights enforcement and enhancement of participation, within a framework of empowerment. While the law needs to be respected, any sort of connection or complicity with any anti-Roma discrimination, harassment or violence should similarly be prevented at all costs by police and other authorities. ${ }^{149}$ The Commission's powers vis-à-vis Member States are usually most visible with regard to the transposition of directives, but its powers in relation to actual law enforcement should not be neglected. ${ }^{150}$ Broader use of

\footnotetext{
${ }^{149}$ The inadequacy of police intervention in cases of anti-Roma violence and harassment (and occasionally even participation in such cases) has been poignantly described in Amnesty International, "We ask for Justice".

${ }^{150}$ See, for example, Article 17 of the Treaty on European Union ('The Commission shall (...) ensure the application of the Treaties'), and Article 258 TFEU (giving the Commission the power to initiate legal proceedings against a Member State for failure to fulfil an obligation under the Treaties).
} 
the Commission's powers to initiate infringement proceedings could address many of the problems which Roma suffer in several contexts, including free movement and political participation.

Günter Grass has been often quoted as saying about the Roma that 'they are what we are forcing ourselves to become: true Europeans'. ${ }^{151}$ That should be cherished and promoted, not neglected and stigmatised. The current legal tools are for the most part appropriate, and EU citizenship status has great potential to allow the Roma minority to improve their socioeconomic status. The necessary political will needs to be harnessed to make full use of the existing legal framework and ensure that enforcement leads to a more humane treatment of the Roma EU citizens.

${ }^{151}$ Gruppo EveryOne, The Roma people in Italy and in the European Union (submission to the delegation to Italy of the European Parliament's Committee on Civil Liberties, Justice and Home Affairs), 13 October 2008, <http://www.genocidewatch.org/images/Italy_08_10_13_The_Roma_people_in_Italy_and_in_the_European_U nion.doc> accessed 30 March 2015; Jean-Pierre Dacheux, Les Roms, marqueurs d'Europe, 5 September 2012, <http://www.ldh-france.org/Les-Roms-marqueurs-d-Europe/> accessed 30 March 2015. 